\title{
Vigilant Eagle: Kazakhstan's Assistance to ISAF in Afghanistan
}

\author{
By Roger N. McDermott
}

Kazakhstan's role in assisting international stabilization efforts in Afghanistan is often underestimated in Western commentaries. The precise nature of that assistance, cooperation with key actors, and level of partnership with NATO can be prone to underestimation, not least due to the tendency to prioritize the role of Russia in the international cooperative matrix. ${ }^{1}$

Yet, if properly understood, these issues convey subtle changes in foreign and defense policy in Astana that may have deeper implications for future peace support or counter-insurgency operations. This paper explores these themes, and argues that Astana actively seeks — on its own terms - ways and mechanisms through which the country might cooperate at a practical level with its Western partners on issues of mutual though not identical interests, as part of a process allowing it to develop a greater international role for itself. Twenty years after gaining its independence, Kazakhstan-like other states in Central Asia-is becoming a more clearly identifiable independent actor both in the region and globally.

Roger N. McDermott specializes in Russian and Central Asian defense and security issues and is a Senior Fellow in Eurasian Military Studies at The Jamestown Foundation in Washington D.C., and a Senior International Research Fellow for the Foreign Military Studies Office (FMSO) at Fort Leavenworth, Kansas. McDermott is on the editorial board of Central Asia and the Caucasus and the scientific board of the Journal of Power Institutions in Post-Soviet Societies. The author wishes to thank the following individuals for reading and commenting on a draft version of this article: Shirin Akiner, Colonel Jon Chicky, and Colonel Christopher Langton. The views expressed in this paper are those of the author alone, and do not reflect any official perspectives.

1 This imbalance in favor of reporting on the role of Russia, and containing passing reference to Kazakhstan or other Central Asian states, is not only apparent in Western media coverage, but also in Congressional Research Service reports. See, for example, Kenneth Katzman, Specialist in Middle Eastern Affairs, Foreign Affairs, Defense, and Trade Division, Afghanistan: Post-War Governance, Security, and U.S. Policy Congressional Research Service Report (Washington, D.C.: Congressional Research Service, 11 January 2007). Evidence given to the U.K.'s Foreign Affairs Select Committee on Afghanistan and Pakistan in reference to Kazakhstan offered strong criticism of the country, arguing it might gain "leverage" over Western governments due to aspects of its assistance to efforts to stabilize Afghanistan. See The UK's Foreign Policy Approach to Afghanistan and Pakistan, Foreign Affairs Select Committee Report, Fourth Report of Session 2010-2011, Vol. 2 (London: House of Commons, 2 March 2011). 
During its first twenty years as an independent state, Kazakhstan's achievements have mirrored the level of ambition and vision for its future development widely shared by its ruling elite. These include the abandonment of the nuclear weapons arsenal inherited from the Soviet Union, its commitment to nuclear non-proliferation, and development of its natural resources. In 2010, Kazakhstan became the first Eurasian state to chair the Organization for Security and Cooperation in Europe (OSCE). The country has experienced significant change during this period, and continues to do so, marked not least by its strategic partnership signed with China in June 2011 and setting the target for Sino-Kazakh bilateral trade at USD 40 billion by $2015 .^{2}$

While the country's cooperation with NATO and assistance to the International Security Assistance Force (ISAF) in Afghanistan in no sense implies any belief in Astana in a military solution to the problem of Afghan security, the drivers behind such cooperative strategies offer potentially invaluable insight into Kazakhstan's political will to more readily participate in international peace support or other operations or initiatives.

\section{NATO-Kazakhstan: A Growing Partnership?}

Any political-military analysis of Kazakhstan's evolving relationship with NATO through Partnership for Peace (PfP) activities (and where this might lead in the future) must begin by identifying the factors that limit the bounds of this relationship. Crucially, Western policy makers and NATO planning staffs all too often underestimate the fact that Kazakhstan is a Eurasian power. ${ }^{3}$ This is not only clear in terms of its geographical location, or its political relations with its powerful neighbors such as Russia or China and its trade ties to these powers as well as others, including the European Union and the United States, but also in terms of self-perception. ${ }^{4}$ The

2 For comparison, Kazakhstan's bilateral trade volume with Russia in 2010 reached approximately USD 15 billion. "Full Text of China-Kazakhstan Joint Statement on AllRound Strategic Partnership," Xinhua Domestic Service (22 June 2011); "Kazakhstan and China to Bring Trade Volume to $\$ 40$ billion by 2015," Interfax-Kazakhstan (14 June 2011). See also Yelena Nikolayevna Zabortsevas (University of Sydney), "Kazakhstan's Bilateral Economic Relations with Russia: a Robust Partnership?" Paper for the BASEES 2010 Annual Conference; available at http://www.paceprojects. co.uk/Zabortseva\%20U\%20\%20of\%20Sydney.pdf.

3 The distinction is an important one and transcends regarding the country simply in terms of its former Soviet history. The transfer of the center of the global economy from the West towards the Asia-Pacific Region will make this distinction all the more important in the future. The use of the term, however, should in no sense be confused with or imply lineage to the Eurasianist philosophy of Aleksandr Dugin.

4 Murat T. Laumulin, The Geopolitics of the $21^{\text {st }}$ Century In Central Asia (Almaty: KISI, 2007), 2-18, 108-12, 150. 
published work of Kazakhstani experts is replete with reference to this Eurasian context, and naturally it also permeates the thinking of governmental institutions. Consequently, the political leadership in Astana often refers to the country as a bridge between East and West. ${ }^{5}$ Viewing the country through a Euro-Atlantic prism, therefore, tends to inherently restrict the potential scope for developing deeper understanding and strengthening ties.

Kazakhstan's close defense and security relationship with Russia also attends to restrict the Alliance's view, in the sense that Astana's historical, cultural, economic, and political links with Moscow must be calibrated into its defense planning. The bilateral relationship with Russia is strong, while defense ties function closely across numerous areas. Kazakhstan's defense ties with Russia are rooted in the Treaty of Military Cooperation signed on 28 March 1994, and more than sixty treaties and bilateral agreements on military issues, including the status of Russian servicemen in Kazakhstan, access to and use of the Baikonur Cosmodrome, and joint military planning. This also extends into joint training and exercises and the development of capabilities within the Collective Security Treaty Organization (CSTO). ${ }^{6}$

This is not simply a matter of protocol or an abstract principle; it feeds into the level of mutual understanding and trust that exists between officers in the armed forces of either state. To give one example, Kazakhstani and Russian officers can meet and discuss the role of what were once known as "political officers" and who now operate as "educational officers," staff for whom there is no Western equivalent: such dialogue would be meaningless to an officer from most NATO member states. ${ }^{7}$ Kazakhstan remains Russia's closest ally, and both have obligations towards each other through the CSTO and the Shanghai Cooperation Organization (SCO). In the country's most recent military doctrine (2007), while cooperation with NATO is mentioned, it is placed in this much wider context of being a member of various multilateral regional and international organizations. ${ }^{8} \mathrm{~A}$ fundamental difference persists: while Kazakhstan is a member of the CSTO, SCO, Conference on Interaction and

5 "Kazakh Speaker, EU Envoy Mull Boosting Ties," Interfax-Kazakhstan (10 March 2009); "Kazakhstan Approves Path To Europe Program," Interfax (4 September 2008).

6 Rossiskaya Federatsiya: Bezopasnosti Voyennoye Sotrudnichestvo, Moscow, 1995; Glavnoye Upravleniye Mezhdunarodnogo Voyennogo Sotrudnichestva Ministerstva Oborony Rossiyskoy Federatsii (Moscow, 1951-2001), 208-12.

7 Yuriy Belousov, "People Are the Important Thing in the Armed Forces," Krasnaya Zvezda (18 October 2008).

8 "Voennaya Doktrina," Kazakhstanskaya Pravda (7 April 2007); available at http:// www.mod.gov.kz/mod-ru/index.php?option=com_content\&view=article \&id=63\&Ite $\operatorname{mid}=151$. 
Confidence-Building Measures in Asia (CICMA), and the OSCE, it is not nor does it plan to become a member of the Alliance. ${ }^{9}$

Additional factors constraining Astana's future partnership with NATO include Kazakhstan's legal obligations to Russia and the CSTO; its CSTO membership, which entails joint air defense and protection of the information space; the presence of Russian military forces in Kazakhstan; weapons and equipment in the inventory remaining largely Russian-made; and misperceptions within Kazakhstani society concerning NATO and its relationship with Central Asia. ${ }^{10}$

There are also sensitivities and misunderstandings that have been exposed during the process of pursuing closer defense ties between NATO and Kazakhstan to which decision makers in Astana are paying closer attention. One factor relates to the military and security assistance offered to the country by the U.S. and its allies, contrasted with its military-technical cooperation with Russia. ${ }^{11}$ While the latter does not result in commensurate political pressures, often there are clear agendas pursued by Washington or other NATO capitals in conducting such cooperation with Kazakhstan, whether it is promoting Western-style democracy or the sense in which such assistance anticipates a quid pro quo. ${ }^{12}$ On the latter score, Kazakhstani decision-makers may often wrongly perceive that the country could be used by its Western defense partners, who are eager for "something in return," although this is simply a political fact of life in the planning and budgetary processes in Western capitals. ${ }^{13}$ If London or Washington did not expect Kazakhstan to "give something in return," many of these cooperative defense ventures would be scrapped. But that is not attempted callous exploitation.

9 M. M. Tazhin, "Natsionalnaya Bezopasnost eto Bezopasnost Cheloveka," Tsentranaya Azia 1 (2007): 6-10.

10 Timur Shaymergenov and Marat Biekenov, "Kazakhstan and NATO: Evaluation of Cooperation Prospects," Central Asia And The Caucasus Journal of Social and Political Studies 11:1 (2010): 46.

11 "Legal Framework for the Russian Arms Exports Moscow," Moscow Defense Brief, available at http://mdb.cast.ru/mdb/3-2001/ec/lfrae/; Anatoliy Antipov, "VPK Is Prescribed for the Defense Establishment," Krasnaya Zvezda (25 March 2006); Igor Khripunov, "The Politics and Economics of Russia's Conventional Arms Transfers," Dangerous Weapons, Desperate States (New York: Routledge, 1999), 132-33.

12 D. A. Feigenbaum, Deputy Assistant Secretary for South And Central Asian Affairs, U.S State Department, "Kazakhstan and the U.S. in a Changed World," Remarks To The Institute of World Economy And Policy, Almaty, 23 August 2006; E. Rumer, "The U.S. Interests and Role in Central Asia After K2," Washington Quarterly (Summer 2006): 141-54; S. F. Starr, “A Partnership For Central Asia,” Foreign Affairs 84:4 (July/August 2005): 169.

13 Author interviews with NATO officials, January 2010. 
Equally, Western approaches to such defense cooperation inevitably give rise to multiple issues that the recipient country struggles to manage. There are, for instance, so many funding streams, departments, and activities involved in Washington delivering such assistance that Astana's planning staffs would struggle to differentiate and maximize the possible benefits. Too often, U.S. defense assistance is diffuse, less narrowly focused on a more realistic set of objectives, and tends to pursue highprofile "deliverables," with photo opportunities for U.S. officials as they are seen handing over military equipment. ${ }^{14}$ Problems are also in evidence in the training and education provided to Kazakhstani military personnel. For several years, it was a sensitive issue that Western military trainers arriving to provide in-country training to their Kazakhstani counterparts were sergeants; this reflected the gulf that existed in the concept and use of Western non-commissioned officers (NCOs) and the Russianinspired "model." ${ }^{15}$ Unlike the Russian armed forces, which (despite the reform announced in October 2008) still reveal little conceptual understanding or progress on the issue of developing an NCO corps, Kazakhstan has made significant progress in this area by benefiting from NATO training and assistance. ${ }^{16}$

An extensive study conducted in Kazakhstan in 2008 examined views of NATOKazakhstan cooperation among the country's expert community. Among its findings were that PfP was considered practically important by only 25 percent of the experts polled, while 15 percent regarded it as a matter of protocol and 60 percent viewed it as being purely symbolic. Only 10 percent believed that military exercises held in the region by the CSTO, SCO, or NATO contributed to security. ${ }^{17}$

Surprisingly, however, the authors of the analysis of the extensive opinion polling found that the expert community was optimistic about the future of cooperation with NATO:

Cooperation between Kazakhstan and NATO is assessed as favorable for the former's geopolitical and military interests while a detailed analysis of the answers demonstrated that the expert community on the whole is fairly optimistic about potentially closer cooperation. This is confirmed in particular by the high share

14 Lieutenant-Colonel Michael J. McCarthy, The Limits of Friendship: U.S. Security Cooperation In Central Asia (Maxwell Air Force Base, AL: Air University Press, October 2007), 92, 178.

15 Roger D. Kangas, "Battling Misperceptions: Challenges to U.S. Security Cooperation in Central Asia," Joint Forces Quarterly 50 (2008): 98-104.

16 Author interviews with U.S. and U.K. officers, June 2010, April 2011. See Vitaly Shlykov, "Spineless Army," Voyenno Promyshlennyy Kuryer (12 April 2011); available at http://vpk-news.ru/articles/7426.

17 Askar Abdrakhmanov and Timur Shaymergenov, "NATO in the Contemporary World and its Relations with Kazakhstan (According to an Expert Opinion Poll)," Central Asia And The Caucasus Journal of Social and Political Studies 6:54 (2008): 43-54. 
of positive answers to the question of possible correlation of NATO and CSTO standards in Kazakhstan's army. The expert community also agrees that closer military-political cooperation with the United States and NATO will hardly create risks for Kazakhstan; even if they do emerge Astana, according to the widely shared opinion, will be able to settle any disagreements by diplomatic means. ${ }^{18}$

Such apparent confidence among Kazakhstani experts explains the fact that, despite the limits placed on such cooperation, Astana has managed these complex processes without damaging relations with its allies. ${ }^{19}$ This may be a product of the country's leadership remaining committed to a "multi-vector" foreign policy, but in reality it is more complex. Decision makers in Astana identify the scope for maneuver inherent in balancing the country's national interests, assessing the various influences of close allies and other powers, and implementing policy accordingly. ${ }^{20}$

Two conceptual errors are prone to creep into Western defense cooperation planning in relation to Kazakhstan: either that Russia has overwhelming or at times too much influence in Astana, or that there are "pro-Western" officials or factions within the Kazakhstani governmental apparatus. Both are wrong, equally mechanical, and open to misreading the situation. There are no "pro-Western" factions mysteriously influencing or guiding decisions in the Kazakhstani power structures: the bureaucracy militates against the emergence of such factions, and is rather designed to facilitate the formulation of policy in the national interests of Kazakhstan. ${ }^{21}$ Moreover, despite the constant fluctuations in Russia's relations with NATO, including these relations being frozen for six months following the Russia-Georgia War of August 2008, Kazakhstan has gradually built a solid partnership with the Alliance.

Ibid.

Ibid.

Author interviews with Russian specialists on Central Asia, Moscow, October 2010.

Author interviews with experts from Kazakhstan, Russia and Uzbekistan, Tashkent, April 2008. 
Table 1: Milestones in the NATO-Kazakhstan Partnership

\begin{tabular}{|c|c|}
\hline 1992 & $\begin{array}{l}\text { - Kazakhstan joins the North Atlantic Cooperation Council, } \\
\text { renamed the Euro-Atlantic Partnership Council in 1997 }\end{array}$ \\
\hline 1995 & $\begin{array}{l}\text { Kazakhstan officially joins the Partnership for Peace (PfP) } \\
\text { - Kazakhstan is connected to the Virtual Silk Highway. } \\
\text { - Kazakhstan joins the PfP Planning and Review Process (PARP). }\end{array}$ \\
\hline 2002 & $\begin{array}{l}\text { - At the Istanbul Summit, Allied leaders place special focus on } \\
\text { Central Asia - a special NATO representative and a liaison } \\
\text { officer are assigned to the region. }\end{array}$ \\
\hline 2004 & $\begin{array}{l}\text { - Kazakhstan delivers its IPAP presentation document to NATO } \\
\text { - Kazakhstan and NATO agree on Kazakhstan's first IPAP, } \\
\text { covering the 2006-2008 period, and on its current set of 2006 } \\
\text { Partnership Goals in the PARP }\end{array}$ \\
\hline
\end{tabular}

\begin{tabular}{|l|l|}
\hline 2006 & \\
\hline & - The President of Kazakhstan, Nursultan Nazarbayev, visits \\
NATO HQ \\
- The 2007 PARP Assessment documents the state of \\
implementation of Partnership Goals \\
- The NATO Science Partnership Prize for 2007 is awarded to \\
two scientists from Kazakhstan and the United Kingdom for \\
excellent collaboration on assessing radioactive contamination at \\
the nuclear test site at Semipalatinsk, Kazakhstan, which was \\
operated by the former Soviet Union \\
- The NATO Information Center opens at the Al Farabi \\
University \\
- NATO depository library is inaugurated at the National Library \\
- Kazakh Defense Minister, Daniyal Akhmetov, visits NATO \\
Headquarters and briefs the North Atlantic Council on the IPAP \\
results for the period of 2006-2008
\end{tabular}

Source: http://www.nato.int/issues/nato-kazakhstan/index.html

As illustrated in Table 1 above, Kazakhstan has made significant progress in its cooperation with NATO, aspects of which are unique within the region. These PfP arrangements were propelled forward in the aftermath of the terrorist attacks on New York and Washington on 11 September 2001 (9/11) and the resulting "War on Terror," while at a regional level in 2005 following the decision by Tashkent to close the U.S. military base at Kharshi-Khanabad (K2) as relations between the U.S. and Uz- 
bekistan deteriorated. These processes were complex and already underway in 2004, with Astana expressing greater interest in entering IPAP. While the former catalyst led to Kazakhstan joining the NATO Planning and Review Process (PARP) in 2002, the latter regional shift in 2005 also precipitated the Alliance to refocus its cooperation efforts in Central Asia away from Uzbekistan and towards Kazakhstan. ${ }^{22}$ The U.S. was also in transition from prioritizing Uzbekistan as an operational-strategic focus in the war on terror, shifting towards Kazakhstan as a geostrategic or geopolitical regional priority. Consequently, by 2006 this intensification culminated in Kazakhstan signing the Individual Partnership Action Plan (IPAP), marking a deepening of Astana's cooperation with the Alliance across a whole range of activities. ${ }^{23}$

Signing the IPAP agreement in 2006 represented a highly significant step, not least since Kazakhstan became the first country in Central Asia to cooperate with NATO at this level. Although Kazakhstan's military doctrine (2007) mentions the Alliance in the context of other regional and international multilateral organizations, it did indicate areas in which it would cooperate with the Alliance, albeit vaguely framed. This was also linked as a driver in developing defense and security ties with the U.S., U.K., Germany, and Turkey as NATO members, and envisaged the PfP cooperation influencing security, military-technical issues, and the country's international military cooperation..$^{24}$

22 The Planning and Review Process (PARP) is open to PfP states on an optional basis, and utilizes NATO's extensive defense planning experience as a tool of engagement with its partners. PARP is a biennial process that includes bilateral and multilateral formats. In the planning cycle, a member of PARP provides information across a number of defense planning issues, among which feature democratic control of the armed forces, and financial and economic planning. On the basis of the PARP a Planning and Review Assessment is then formulated, and partnership goals are outlined as well as measures geared towards their achievement. NATO Handbook, Chapter 3: "The Opening Up of the Alliance: Partnership for Peace: The Partnership for Peace Planning and Review Process (PARP)" (Brussels: NATO, 8 October 2002).

23 The Individual Partnership Action Plan (IPAP) serves as an extra mechanism for members of the Alliance to provide support and advice to PfP members. The IPAP is requested by individual members of PfP in order to "prioritize, harmonize, and organize all aspects of NATO-partner relationships" via EAPC and PfP. "NATO will provide its focused, country-specific assistance and advice on reform objectives that interested partners might wish to pursue in consultation with the Alliance." "Ministerial Meeting of the North Atlantic Council, Held in Madrid on June 3, 2003: Final Communiqué," NATO Press Release, 3 June 2003.

24 See http://www.mod.gov.kz/mod-ru/index.php?option=com_content\&view=article\&i $\mathrm{d}=63 \&$ Itemid $=151$. 
Participation in PARP acted as a mechanism by which Alliance standards and procedures were encouraged to influence reform, force structure, and training in Kazakhstan's armed forces. Astana's participation in PfP through a variety of partnership mechanisms and in the Euro-Atlantic Partnership Council (EAPC) provides opportunities to hold political dialogue with NATO and coordinate its cooperation in areas as diverse as peacekeeping, military reform, prevention of emergencies, and environmental protection. Specialists in Kazakhstan have noted that Washington acted as a powerful driving force in these processes, and indeed its willingness to sign five-year bilateral cooperation plans with the U.S. indicated a longer-term planning commitment to such partnerships, and by implication a deeper interest in NATO. ${ }^{25}$

Traces of the potential dividends and problems involved in such deepening NATOKazakhstan cooperation appeared in 2010-11, as both sides explored the limits of the partnership. In January 2010, the second stage of Kazakhstan's IPAP was approved and adopted in Brussels during a meeting of the so-called "NATO + Kazakhstan" format. The Kazakhstani defense ministry delegation was led by Lieutenant-General Bolat Sembinov, Deputy Defense Minister, who confirmed that the IPAP extended the process of modernizing Kazakhstan's armed forces, enhancing operational interoperability with NATO forces, improving cooperation in science, emergency civil planning, and environmental issues, and in combating terrorism. ${ }^{26}$

On 6 May 2010, NATO Secretary-General Anders Fogh Rasmussen met the head of Kazakhstan's mission to NATO, Yerik Utembayev, ostensibly to discuss regional security and the progress of Astana's participation in PfP. Utembayev strongly advocated closer cooperation with the Alliance, and specified Astana's interest in strengthening cyber security, using modern technologies in defense and civil planning, and intensifying the sharing of experience through NATO's Science for Peace and Security Program. Both officials praised the existing level of cooperation, while Rasmussen suggested "studying joint principles for seeking a stronger partnership and expressed interest in continuing to step up work with Kazakhstan on some key problems." The NATO Secretary-General also praised Astana for its active efforts to settle the security situation in neighboring Kyrgyzstan after the downfall of its president, Kurmanbek Bakiyev. ${ }^{27}$ Both sides discussed the implementation of the

25 M. Laumulin, "Strategicheskie Aspekty Otnosheniy Kazakhstana s Zapadom: SSha, NATO," in Kazakhsta v Sovremennom Mire: Realii I Perspektivy, ed. B. Sultanov (Almaty: KISI, 2008); M. Nurgaliev, "Kazakh-US Military-Political Cooperation in the Context of US Geopolitical Interests in Central Asia, Central Asia And The Caucasus Journal of Social and Political Studies 2:44 (2007).

26 Sembinov was dismissed from the post in November 2010. "Second Stage of KazakhNATO Partnership Plan Adopted," Interfax-Kazakhstan (20 January 2010).

27 "Kazakhstan Advocates Closer Ties With NATO," Interfax (7 May 2010); "Kazakhstan Boosting Partnership with NATO-Envoy," Interfax-Kazakhstan (6 May 2010). 
IPAP during a four-day visit to Kazakhstan by NATO officials led by Robert Simmons, the NATO Secretary-General's Special Representative for the South Caucasus and Central Asia. Simmons held talks with Kazakhstan's Defense Minister, Adilbek Dzhaksybekov, as well as General Sembinov. A preliminary assessment of IPAP's implementation and partnership objectives was discussed with representatives from nineteen Kazakhstani governmental agencies. ${ }^{28}$

In May 2011, senior parliamentarians in Kazakhstan were also calling for deeper practical cooperation with the Alliance, and the frequency of contact with NATO officials suggested that critical issues were being discussed beyond the public diplomacy. ${ }^{29}$ These factors related to the U.S. and its allies actively developing alternative supply lines for their forces deployed in Afghanistan, as the Pakistan route proved to be increasingly vulnerable, in addition to efforts to persuade Astana to send military forces to Afghanistan. Agreement in principle for Kazakhstan to support opening the Northern Distribution Network (NDN) as an additional route to replenish supplies to deployed forces in theater initiated a period of intense negotiation and fulfilling domestic ratification processes both on the NDN and contributing to ISAF.

\section{The Northern Distribution Network: Kazakhstan's Role}

Kazakhstan's relationship with NATO and its assistance to ISAF in Afghanistan markedly increased in 2008-10 due to the exposure of military supply lines through Pakistan into Afghanistan to attacks by the Taliban and local bandits. The underlying cooperative dynamics between Astana and the Alliance are likely to endure for many years, not least in terms of efforts to stabilize Afghanistan. U.S. Department of Defense (DoD) agencies such as United States Transportation Command (USTRANSCOM) had relied heavily on the Pakistan Ground Line of Communications (PAKGLOC) to move cargo for forces deployed in Afghanistan. In September 2008, U.S. Central Command (CENTCOM) approved an alternative ground supply line, and following successfully testing the route by May 2009 it was operational. The surge policy long mooted and finally announced by U.S. President Barack Obama on 1 December 2009 to boost U.S. forces in ISAF by more than 30,000 troops only added additional impetus to reactivate and develop NDN routes to Afghanistan

28 "Kazakhstan, NATO to Extend Cooperation to Ensure Regional Security," "NATO Experts Visit Kazakhstan To Boost Cooperation," Interfax-Kazakhstan (15 October 2010).

29 "Kazakh Servicemen Attend Seminar on NATO Peacekeeping Operations," InterfaxKazakhstan (13 June 2011); "Kazakh Senate, NATO Official Call for Closer Cooperation," Interfax-Kazakhstan, "NATO Can Help Kazakhstan Conduct Army ReformOfficial," Interfax (13 May 2011). 
through Central Asia, originating from seaports in the Baltic States. In December 2008, a bilateral agreement in principle was reached between Washington and Astana for Kazakhstan to participate in the NDN. The sheer complexity of devising and implementing such intricate networks, with the bilateral and multilateral agreements required in each of the transit countries, naturally often resulted in misperceptions and diplomatic shortcomings. ${ }^{30}$

Central Asia had experienced prototypes of this system. In 2004-05 the U.S. Defense Logistics Agency (DLA) had developed a distribution network originating in Gemersheim, Germany, transiting cargo to Bagram in Afghanistan through Austria, Hungary, Bulgaria, Azerbaijan, Turkmenistan and Uzbekistan. Transportation-related and other complications meant that the northern route mainly facilitated movements of goods such as construction materials or bottled water, or lumber using seaports. Following the closure of the U.S. airbase in Kharshi-Khanabad, Uzbekistan, by late 2005 the route fell into disuse. ${ }^{31}$

As U.S. troop numbers deployed to Afghanistan increased year-on-year, a market survey in 2007 re-examined the northern ground supply line, and by September 2008 the route was successfully tested, taking plywood in ten containers from Germany to Bagram. ${ }^{32}$ The Baltic-to-Afghanistan, or "Russian route," was first successfully tested in March 2009. A critical goal in re-establishing a northern supply line was to reduce dependence on the PAKGLOC, and during the surge of U.S. troops in 2010 the NDN accounted for 30 percent of the total supplies brought into Afghanistan.

Jim Nichol, in a Congressional Research Service report in March 2010, noted the proactive nature of U.S. diplomacy with a number of NDN participating countries, including the Central Asian states, and its intensification in 2008-09:

To encourage a positive response, the U.S. embassies in the region announced that the United States planned to purchase many non-military goods locally to transport to the troops in Afghanistan. Kazakhstan and Tajikistan agreed in principle to such transit in February 2009 (although technicalities were not worked out with Kazakhstan until 2010), Uzbekistan permitted it in April 2009, and Kyrgyzstan permitted it in July 2009 (Georgia had given such permission in 2005, Russia in 2008, and Azerbaijan in March 2009). A first rail shipment of non-lethal supplies

30 Andrew C. Kuchins and Thomas M. Sanderson, The Northern Distribution Network and the Modern Silk Road: Planning for Afghanistan's Future (Washington, D.C.: Center for Strategic and International Studies, 2009); Andrew C. Kuchins and Thomas M. Sanderson, The Northern Distribution Network and Afghanistan (Washington, D.C.: Center for Strategic and International Studies, 2010).

31 Col. Kurt J. Ryan, "Exploring Alternative Strategic Access To Afghanistan,” U.S. Army War College, 2009.

32 Ibid. 
entered Afghanistan in late March 2009 after transiting Russia, Kazakhstan, and Uzbekistan. ${ }^{33}$

\section{Figure 1: Defense Logistics Agency: Northern Distribution Network}

\section{$D L A$ on the NDN}

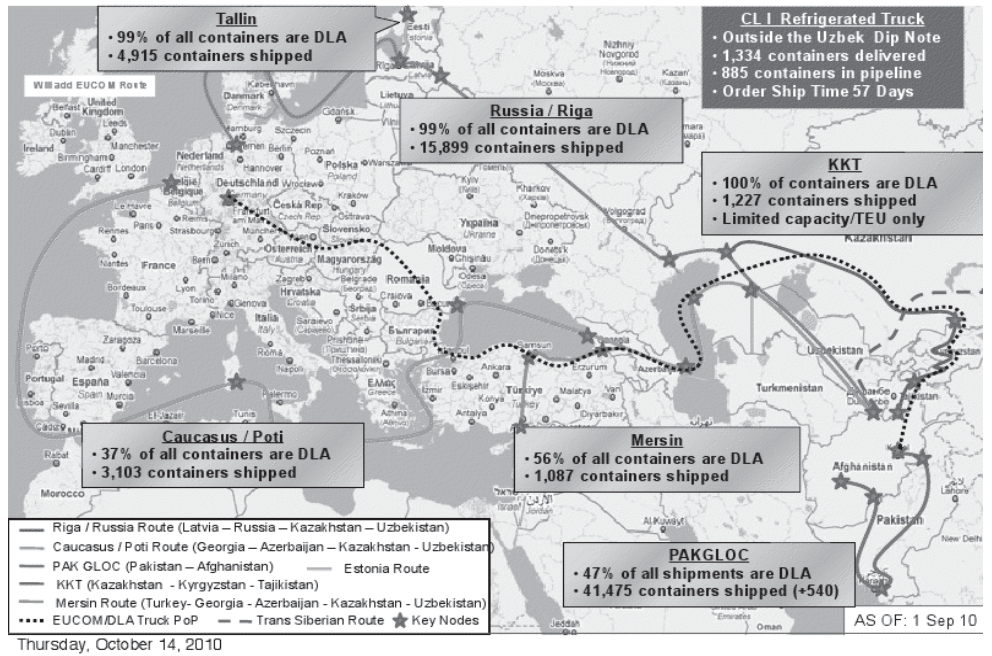

The sheer scale of the undertaking, involving managing multiple interests and agencies, as well as local political sensitivities reflected the mammoth task of finding alternatives to one of the longest supply lines in military history. As shown in the DLA map (Figure 1), the NDN has several points of origin: the Latvian ports of Riga, Tallinn (Estonia), and Klaipeda (Lithuania), as well as the Turkish port of Mersin and the Georgian port of Poti. From northern Germany and the Baltic States, the route known as the Russian route moves cargo south through Russia, Kazakhstan, and Uzbekistan prior to reaching Afghanistan. Within Central Asia, an additional option to taking supplies through Uzbekistan is the Kazakhstan, Kyrgyzstan, and Tajikistan (KKT) spur. The Mersin route joins the South Caucasus route (where supplies can originate from Belgium) at the Black Sea port of Poti, Georgia, while supplies transit Azerbaijan, the Caspian Sea, Kazakhstan, and Uzbekistan. There are also key nodes and air lines of communication (ALOC) involved in the NDN (shown on the map).

33 Jim Nichol, Central Asia's Security: Issues and Implications for US Interests, Congressional Research Service Report (Washington, D.C.: Congressional Research Service, 11 March 2010). 
Yet, a number of additional observations should be noted concerning the complexity of the NDN before considering issues from Astana's perspective. ${ }^{34}$

Clearly, Russia's participation is crucial to the successful functioning of the NDN, though one and technically two NDN routes do bypass Russia. Uzbekistan is considered by specialists on the NDN such as Thomas Sanderson to be the "fulcrum" of the route, as much of the cargo passes through the country before crossing into Afghanistan at Termez in southern Uzbekistan; specifically, two routes transit supplies in the NDN using Uzbekistan (or three if the less used Trans-Siberian spur is included). However, the Russian route hinges on access across Kazakhstan's territory. Moreover, Kazakhstan features twice (in the Russian route and the KKT, though the latter is less frequently used) and technically four times (Mersin/South Caucasus routes, including U.S. European Command (EUCOM)/DLA truck deliveries through the South Caucasus) or five if the Trans-Siberian route is also included. Different road and rail options within the countries active in these NDN routes make the supply line truly networked and complex. NDN stakeholders also recognize the limits of the NDN routes. For instance, in the case of the KKT, in winter it is restricted to twentyfoot equivalent units (TEUs) and at other times it can take up to seventy days to transit supplies, while all lumber must route through Klaipeda or Tallinn (not Mersin/ Poti) unless an original phytosanitary certificate can be obtained. ${ }^{35}$

Cargo originating in Europe or the Eastern part of the U.S. transits the NDN, while cargo from the CENTCOM's Area of Operations (AOR) and the West Coast of the U.S. moves through the PAKGLOC. Most military equipment and Foreign Military Sales (FMS) cargo is restricted to the PAKGLOC, though some FMS materials can use the NDN on a case-by-case basis subject to appropriate approvals. There are also restrictions on moving refrigerated cargo through the NDN. Moreover, transiting supplies through the KKT spur restricts shipments to 20-foot TEUs, while many routes allow the delivery of 40 -foot containers, or two TEUs. ${ }^{36}$

In April 2010, General David Petraeus, then Commander of CENTCOM, stated the U.S. had purchased more than USD 62 million worth of construction materials and bottled water in Kazakhstan to send to Afghanistan. ${ }^{37}$ According to the U.S. State Department, by March 2011 almost 27,000 containers were sent through Russia using the NDN. "At this time, 50 percent of U.S. sustainment cargo for Afghanistan goes through the Northern Distribution Network and 60 percent of supplies transiting

34 "Military Surface Deployment and Distribution Command Customer Advisory," CA10-12/13-0307, 13 December 2010.

35 Ibid.

36 Ibid.

37 U.S. Embassy in Astana, Press Release, "General David H. Petraeus, Commander, U.S. Central Command and Richard E. Hoagland, U.S. Ambassador to Kazakhstan: Media Roundtable," 5 April 2010. 
that network go through Russia. This is a significant benefit for the United States," U.S. Assistant Secretary of State for European and Eurasian Affairs Philip Gordon told a hearing at the Senate Foreign Relations Subcommittee on European Affairs. Air supply lines have transported troops and lethal cargo, while most cargo through the NDN remains non-lethal. By spring 2011, Moscow had granted permission for more than 1,000 flights carrying over 170,000 military personnel en route to Afghanistan (the figure is based on the total of rotated troops deployed in theater)..$^{38}$

In May 2009, Russian Foreign Minister Sergei Lavrov confirmed that lethal cargo is also involved in the NDN, and that pre-existing bilateral agreements had allowed such supplies for NATO forces to transit Russian territory: "It is only one year ago that we signed an agreement with NATO as an organization for non-lethal transit, but for many years lethal transit had been operating through Russia on the basis of our bilateral agreements with France, Germany, and recently the similar agreement with Spain was signed. They can move equipment, troops." ${ }^{39}$ However, the question of lethal supplies is a highly sensitive issue for some of the NDN transit countries.

In July 2008, Alan E. Haggerty, U.S. Deputy Under Secretary of Defense (International Technology Security), highlighted the huge importance of the issue of logistics, stating that it accounts for approximately 50 percent of DoD personnel and one third of the DoD's budget. Moreover, Haggerty said that when the U.S. military deploys, around 70 percent of the tonnage moved is fuel, and that half the current level of casualties is linked to convoys. In other words, the U.S. armed forces consume large sums of money and lose personnel in the process of moving fuel around. ${ }^{40}$

In November 2009, a Deloitte study of five previous U.S. military operations concluded that on average the U.S. military used 22 gallons of fuel per day for each soldier deployed. ${ }^{41}$ Since Afghanistan has no hydrocarbon resources to meet these demands, naturally this has resulted in spiraling costs to send fuel into the country, not only for combat missions, but to supply the entire supporting structure. Washingtonbased analyst John C. K. Daly contrasted the staggering sums involved in the context of the low cost of fuel in the U.S. for domestic consumers compared with the costs per gallon of JP-8 (the fuel commonly used by the U.S. armed forces). "In October 2009, Pentagon officials testified before the House Appropriations Defense Subcommittee that the 'Fully Burdened Cost of Fuel' (FBCF) translates to about USD 400 per gallon by the time it arrives at a remote Forward Operating Base (FOB) in Afgha-

38 Phillip Gordon, "Statement to U.S. Senate on Afghanistan," 31 March 2011.

39 John C. K. Daly, “Rerouting Logistics In Afghanistan,” ISN (17 May 2010).

40 Alan E. Haggerty, Deputy Under Secretary of Defense (International Technology Security), "S\& T and Maneuver Warfare: A Current Success and a Future Challenge," 29 July 2008; available at http://www.dtic.mil/ndia/2008maneuver/Haggerty.pdf.

41 "Energy Security: America's Best Defense," http://www.deloitte.com/assets/DcomUnitedStates/Local\%20Assets/Documents/AD/us_ad_EnergySecurity052010.pdf. 
nistan. Last year, the FBCF reached USD 800 in some FOBs following supply route bombings in Pakistan, while others have claimed the FBCF may be as high as USD 1,000 per gallon in some remote locations." ${ }^{42}$

Such spiraling fuel costs may compel the DoD to pursue options in the future to reduce the U.S. military's level of fuel dependency. In support of Operation Enduring Freedom (OEF) and ISAF operations in Afghanistan, much of the fuel originates in Russia, and the limited refining capacity in Central Asia has not offset this paradoxical Russian contribution to the war and stabilization efforts. Kazakhstan certainly has untapped potential in the future to expand its contribution in this area, offsetting the fuel costs for Western forces deployed in Afghanistan (in whatever capacity).

NDN routes continue to evolve, driven by the need to improve fuel efficiency. On 5-6 June 2011, following two years of negotiations with Moscow and Astana, a new air supply line opened across the Arctic, Russia, and Kazakhstan. A U.S. Air Force C-5M Super Galaxy used the route to fly from Dover Air Force Base in Delaware to Bagram airbase. On 21-22 June 2011, a U.S. Air Force KC-135 Stratotanker used the Arctic ALOC flying from Fairchild Air Force Base in Washington to the Manas Transit Center in Kyrgyzstan, marking the first flight of an air refueling tanker using the route, reportedly saving USD 54,000 and cutting flight time by 4.5 hours. ${ }^{43}$

Philip Gordon also told the U.S. Senate that "our relations with Kazakhstan are perhaps our deepest and broadest in Central Asia, with cooperation across a broad range of fields as diverse as non-proliferation, support to Afghanistan, energy and health." Praising Astana for its commitment to nuclear non-proliferation and its position in the global energy market, Gordon commented on the country's importance in the context of Afghanistan: "Kazakhstan provides vital logistical support to the International Security Assistance Force (ISAF) through the NDN. Kazakhstan is also investing in Afghanistan's next generation of leaders through a USD 50 million scholarship program to educate one thousand Afghan students in Kazakhstan's universities." ${ }^{44}$

During a plenary session of the Senate, the upper house of Kazakhstan's parliament, on 14 April 2011, approval was finally given to the draft law ratifying the agreement reached between Astana and Washington in relation to the NDN, signed on 12 November 2010. On 3 May 2011, President Nazarbayev signed the bill into law, which allows the air transit of cargo and military personnel through Kazakhstan for

42 John C. K. Daly, “Are ISAF's Tenuous Supply Lines Sustainable?" ISN (2 March 2011).

43 Captain Kathleen Ferrero, "Tanker's First Flight Over Top of the World Marks New Era In Efficiency," 27 June 2011; available at http://www.dvidshub.net/news/72835/ tankers-first-flight-over-top-world-marks-new-era-efficiency.

44 Gordon, "Statement to US Senate." 
operations in Afghanistan. Until this ratification, U.S. cargo transited Kazakhstan under memoranda of understanding between the two governments signed on 15 December 2001 and 10 June 2002, which had facilitated approximately 10,000 flights. These memoranda had opened air supply routes and provided Almaty and Astana airports to be used in cases of bad weather or emergency landing for U.S. military air transit to Manas, Kyrgyzstan, which has been used on numerous occasions. Astana also used these early agreements in support of OEF to expand the number air corridors as well as allowing lethal-and non-lethal cargo to transit the country. According to Kayrat Umarov, the Deputy Foreign Minister, the law now displaces the earlier memoranda and regulates the system for securing the appropriate permission for the transit of cargo and personnel through Kazakhstani airspace, providing compensation for any loss or damage incurred, and strengthens the country's proactive role in assisting in the efforts to stabilize Afghanistan. ${ }^{45}$

Such legislation was also important in the context of the shifting balance between the NDN and PAKGLOC, since by March 2011 the level of supplies through the NDN increased from 30 percent to 50 percent. Kazakhstan's participation is now enshrined in law. This may well further scale back dependence on the PAKGLOC, and seems to provide ample testimony to the successful development of the NDN including routing supplies through Central Asian nodes such as Navoi airport in Uzbekistan, using South Korean airlines to transit goods and personnel to Afghanistan. ${ }^{46}$ Further shifting the supply route balance in favor of the NDN is the fact that the growth in commercial activity and infrastructure projects in the region is set to increase the amount of cargo transported on the route by as much as 75 percent by late 2011 as a result of Washington's plans to expand NDN through negotiating expanded agreements with key Central Asian participants. ${ }^{47}$

\section{NDN's Wider "Strategic" Context}

The NDN is evidently a complex network demanding equally sophisticated Western diplomacy, particularly with both Russia and the Central Asian participants. Understandably, given the scope for misunderstandings in such innovative ventures, setbacks and time-consuming issues are a predictable byproduct. Since NDN dip-

45 "Kazakhstan Ratifies Afghan Cargo Air Transit Agreement With The U.S.," InterfaxAVN (3 May 2011); "Kazakh Parliament Ratifies Treaty On Transit Of U.S. Cargo To Afghanistan," Interfax-Kazakhstan (14 April 2011).

46 "NATO Increases Afghan Cargo Transfers Through Central Asia," www.centralasiannewswire.com (22 March 2011).

47 "U.S. Shifts Supply Routes To Central Asia," Radio Free Europe/Radio Liberty (3 July 2011). 
lomacy began, Astana has consistently supported the routes as well as the increased commercial opportunities that attended its participation. Russia's participation, like that of the Central Asian states, was considered by Western decision makers to be a "win-win" policy to pursue given its intrinsic link to the "reset" in bilateral relations that Washington conducted with Moscow. Indeed, the logistical dynamics associated with the surge policy may well have influenced and driven the reset policy, at least initially, since there were so few realistic transport options without Moscow's active support. ${ }^{48}$

Kazakhstan is by no means isolated in having certain sensitivities surrounding how the process of its participation in the NDN functions, or the level of its support for OEF and assistance to ISAF. All Central Asian states have security concerns linked to possible risks stemming from future Taliban "bleed-out" in the region, particularly following the completion of the transition now underway to pass responsibility for Afghanistan's security to the government in Kabul. ${ }^{49}$ Equally, from Kazakhstan's perspective, concerns about the flow of illegal drugs from Afghanistan through Central Asia and into Russia are a serious and constant security concern, and these do not always afford opportunities for agreement with its Western partners. SCO member states frequently raise anxieties about this issue, and what is perceived as ISAF's failure to adequately address it. ${ }^{50}$

Astana, consequently, wishes to avoid attention being drawn to troop or lethal supplies transiting the country. To date, the Western governments have handled this issue adroitly. Kazakhstan's government, like others in the region, would readily assign a place of great importance to Moscow's proactive assistance and participation in the NDN, not least since, beneath the official rhetoric, Russia recognizes that its own vested security interests are at stake in Afghanistan. ${ }^{51}$ However, according to leaked diplomatic traffic, Astana did take exception to the over-emphasis placed on Russia by Western capitals, and in particular objected to a "Russia first" approach that implied second-rate treatment at worst, or at best its contribution being undervalued.

The diplomatic memo prepared by the U.S. Embassy in Astana as a briefing for General Petraeus ahead of his visit to Kazakhstan in March 2009 noted the nature of the problem:

Of note is that the government of Kazakhstan was extremely unhappy that NATO sought permission of its big brother to the north before opening discussions with

\footnotetext{
48 Author's discussions with U.S. experts, Washington, D.C., 28 June 2010.

49 "Kazakhstan Faces Serious 'Extremist Threats'-Analyst," Interfax (23 June 2011); "Kazakh Intellectuals Voice Concern Over Islamic Sect Activities," Zhas Alash (22 June 2011).

50 V. V. Evseev, “Afganskaya Problema: Vzglyad iz Moskvy,” Nezavisimoye Voyennoye Obozreniye (19 March 2010).

51 "Kazakhstan Faces Serious Extremist Threats."
} 
the Kazakhstanis, the government indicated negotiations should have occurred in parallel rather than in serial. The German government negotiated an official government-to-government agreement with Kazakhstan for the ground and air transit of both lethal and non-lethal supplies destined for Afghanistan, which took three years to negotiate (2004-2007) and one year for parliamentary ratification before the agreement entered into force in 2008 - a four year process. The Germans have yet to execute the transit of lethal goods via ground means, something we will monitor in the event the U.S. decides to expand its current agreement to include the transit of lethal supplies. ${ }^{52}$

Examining the leaked material in its context, allowing for errors and an appearance of a hurriedly produced overview for a senior defense official, there are aspects of the reflection on NDN diplomacy that demand closer scrutiny. At face value, the memo refers to a problem in how Astana perceived the actions of U.S. diplomats, and the primacy attached to Russia as part of the process. It appears that Astana was not questioning the valuable role played by Moscow in its decision to support the NDN, but rather that Kazakhstan was being treated as an after-thought rather than in parallel. Nonetheless, throughout the memo the level of understanding of Kazakhstan on the part of U.S. diplomats is surprisingly low. ${ }^{53}$ It is especially worth noting the phrase "little brother" used in referring to Kazakhstan's complex relations with Russia. Washington and Brussels consistently oppose Moscow's references to Central Asia as constituting part of Russia's "sphere of privileged interests" while often inadvertently recognizing its de facto existence by adopting a mechanical approach to relations with Kazakhstan, based on first factoring in the issue of Russia's relationship with the U.S. or NATO.

In fact, across a wide range of bilateral and multilateral defense cooperation initiatives, as well as Astana's support for ISAF, Kazakhstan is clearly an independent Eurasian actor, and there is no contradiction between this reality and its close relations and alliance with Russia. Grasping this more fully and consistently in the future may well unlock for Western planning staffs deeper and more durable cooperative initiatives with Kazakhstan. Aspects of these dynamics underpin the country's approaches and willingness to cooperate with NATO and its members on a level that is unique in Central Asia, and often much more advanced than Russia's military cooperation with the Alliance.

\footnotetext{
52 http://www.wikileaks.ch/cable/2010/02/10ASTANA251.html, accessed on 20 June 2011.

53 Ibid.
} 


\section{Kazakhstan's Peace Support Operations Capabilities}

Since 2003, the focus of NATO's training assistance to Kazakhstan has centered upon developing the country's Peace Support Operations (PSO) capabilities. This envisaged training members of Kazakhstan's peacekeeping battalion (KAZBAT) in-country on a "train-the-trainer" basis, raising standards and progressing towards such force elements becoming interoperable with NATO forces. ${ }^{54}$ In this formative period, U.S. planning staffs also considered that such initiatives may enhance Kazakhstan's abilities to respond to crises on the Caspian coast. This in itself involved considerable commitment on the part of the U.S. and U.K. as well as reciprocation by Kazakhstan, and extending to include annual trilateral military exercises, called "Steppe Eagle," which allowed the level of progress in KAZBAT to be monitored and assessed. The U.S. DoD formed bilateral five-year military cooperation plans starting in 2003, and renewed the program in 2008. This serves as a framework document for Foreign Military Financing (FMF), Global Peacekeeping Operations Initiative (GPOI), Train and Equip (TEP), and International Military Education and Training (IMET) programs, as well as facilitating military-to-military cooperation. Its long-term cooperation goals are: strengthening PSO capabilities, enhancing combat readiness in the air defense forces, developing naval capabilities in the Caspian Sea, forming and supporting the Defense Institute of Foreign Languages (DIFL, opened in 2005), and establishing a professional cadre of sergeants. ${ }^{55}$ U.K. defense diplomacy with Kazakhstan is conducted on an annual basis, supporting many of these goals, though less ambitious and more narrowly focused.

NATO sought to assist Kazakhstan to expand its PSO capabilities and potential interoperability by developing the battalion - elements of which were gaining operational experience in a demining role in Iraq - into a fully NATO-interoperable brigade (KAZBRIG).$^{56}$ This transformation of the country's PSO potential, still in progress, has caused a great deal of confusion in Western expert circles, with some mistakenly claiming that the two entities co-exist (KAZBAT plus KAZBRIG). ${ }^{57}$ Attaining this

54 Roger N. McDermott, “Enhancing Kazakhstan's Peacekeeping Capabilities: Interoperability and Regional Cooperation," Central Asia And The Caucasus, Journal of Social and Political Studies 2:26 (2004): 70-82; Roger N. McDermott and Col. Igor Mukhamedov, "Kazakhstan's Peacekeeping Activities In Iraq," Bagdar (Almaty) (March 2004).

55 Kazakhstan Defense Ministry Briefing, Astana, September 2008; “U.S.-Kazakhstan Sign Five Year Defense Cooperation Plan,” Interfax-Kazakhstan (1 February 2008).

56 KAZBRIG is also somewhat oddly known as the $38^{\text {th }}$ Motorized Rifle Brigade, though the unit was probably designated in this manner for administrative purposes.

57 Martha Olcott, "NATO and Security in Central Asia," in Security Sector Reform in Central Asia: Exploring Needs and Possibilities, ed. Merijn Hartog (Groningen: The Centre of European Security Studies (CESS), 2010), 63-72. 
goal, for instance, involved forming a headquarters and logistic support department, three assault companies, fire support, reconnaissance, administrative and military police companies, as well as a medical platoon, which were all to be replicated as additional battalions were formed. Moreover, NATO planners saw this as a pilot project that, if it proved successful, could serve as a model to replicate in other brigades. ${ }^{58}$ There were, however, two critical problems that pre-disposed Kazakhstan's Defense Ministry to be cautious in this venture, and similarly allowed a certain degree of miscalculation on the part of NATO.

These critical and interlinked factors relate to the airmobile forces from which KAZBAT was drawn and NATO's aspiration to eventually move beyond only one brigade assigned for possible international PSOs and Kazakhstan's alliance commitments within an evolving CSTO agenda. While Kazakhstan pursued deeper partnership relations with NATO, and demonstrated openness to this policy and benefitted from the military assistance on offer, it also had to finely balance this against its legal obligations within a regional alliance. If NATO assistance plans conflicted with the country's security interests within the CSTO, inevitably the choice was clearly pre-determined against Brussels. The initial sensitivity NATO engagement with KAZBAT/KABRIG raised was the fundamentally divergent approach in the PSO and Russian-inspired peacekeeping (or peace-enforcement) concepts: both the theory and practice differed widely. The former was alien to Kazakhstani servicemen, demanding and challenging in terms of its approaches, personnel training, weapons, and equipment. High Mobility Multipurpose Wheeled Vehicles (HMMWV, or Humvees), Huey II helicopters, and C-130 transport aircraft, as well as other weapons and equipment, were provided by the U.S. through the Foreign Military Financing (FMF) and Excess Defense Articles (EDA) programs. More than 100 Humvees were taken into service in KAZBRIG, supported by creating a unit maintenance facility. Problems with servicing and spare parts have reduced the effectiveness of the Huey IIs in KAZBRIG. ${ }^{59}$

In May 2009, the U.K. deployed a four-man British Military Advisory Training Team (BMATT) to the Illyski training center near Almaty to work with Kazakhstani instructors trained at Vyskov (the BMATT center located in the Military Academy of the Czech Armed Forces) to strengthen the training of the $2^{\text {nd }}$ Battalion of KAZBRIG. Their role was to train and assist in the preparation of a company HQ training package. Around 165 Kazakhstani personnel ranked from private to captain levels, in addition to eight officers, were trained in PSO tactics, techniques, and procedures (TTPs). The progressive time-phased approach to training KAZBRIG personnel ahead of "Steppe

58 Author interviews with U.S., U.K., and NATO military planners.

59 Partnership for Peace Information Management System, 16 August 2010, available at http://www.pims.org/news/2010/08/23/steppe-eagle-2010-exercise. 
Eagle" also involved an additional two-man BMATT deployed between 31 August to 18 September 2009 to assist in training servicemen in the $1^{\text {st }}$ and $2^{\text {nd }}$ Battalions in KAZBRIG. Over 550 personnel in $1^{\text {st }}$ Battalion and 350 personnel in $2^{\text {nd }}$ Battalion were trained in TTPs, with Kazakhstani trainers encouraged to formulate and deliver the training package. ${ }^{60}$

Members of KAZBRIG (under the command of the Air Mobile Forces HQ, Almaty and co-located with $35^{\text {th }}$ Air Assault Brigade, Kapchagai) reportedly made significant progress in NATO standard approaches to PSOs, both before "Steppe Eagle" annually and in pre-exercise training. Commenting on "Steppe Eagle 2009," Colonel Daulet Ospanov, Deputy Commander of KAZBRIG, said: "This is a huge exercise for us, the benefits are improved relationship with Kazakh and British troops, and they are now like brothers. We look for interoperability, friendship, cooperation and the ethos to rub off on the Kazakhs. The Armed Forces of the United Kingdom have taken part in [operations in] Iraq and Afghanistan. They have a lot of experience and we regard the British Army as very professional and the leading nation at the forefront of peace support operations." U.K. Lieutenant-Colonel Charlie Barnett observed: "They have done a lot of war fighting training, but in order for them to take part in modern operations we need to teach them a different type of tactic, a tactic which allows integration with the civilian population." ${ }^{\prime 61}$ U.S. and U.K. military personnel conducting such annual training helped train KAZBRIG servicemen in mobile and foot patrols, mounting roadblocks, crowd control, dealing with Improvised Explosive Devices (IEDs), tactical support, and in liaising with the local civilian population, acclimatizing them to the intensely demanding nature of modern PSOs. ${ }^{62}$

An important aspect of developing NATO interoperability is the provision of English Language Training (ELT), which is carried out with members of KAZBRIG by U.S. and U.K. training teams. The U.K. has regularly sent BMATTs to work with Kazakhstani servicemen prior to the annual "Steppe Eagle" exercises, and encouraged the command element to maintain this even when the pressure has mounted to cut

60 British Military Advisory and Training Team (Czech Republic), 12 October 2010; available at http://www.mod.uk/DefenceInternet/AboutDefence/CorporatePublications/DoctrineOperationsandDiplomacyPublications/BMATTCZ/.

${ }^{61}$ Author's emphasis. UK Sergeant Phil Houseman explained: "We've been going through basic patrolling skills, so we've been covering just simple principles of patrolling and also going some of the main drills, hand drills that we cover and then moving on to contact drills as well. But we are keeping it at quite a base level and just progressing it, seeing how they progress and then obviously upping the ante as they get a grip of the actual drills." "TA Rifles Hone Their Combat Skills In Kazakhstan," October 2009; available at http://www.army.mod.uk/news/17683.aspx?rating=5.

62 Author interviews with U.S. and U.K. officers. 
back such activity in favor of tactical training. ${ }^{63}$ Progress in this venture, including U.S., U.K., and NATO support to strengthen ELT in Kazakhstan's armed forces has proved to be costly and arduous, though certain milestones have already been achieved. At the NATO level, part of this focus entailed assisting the Kazakhstani defense ministry in its creation of DIFL, though the level of sustained input and monitoring was low. On 27 April 2010 a new language and staff training center was opened in Almaty. U.S. Ambassador to Kazakhstan, Richard E. Hoagland, together with the Airmobile Forces Commander-in-Chief, Major-General Adilbek Aldabergenov, opened the USD 786,000 renovated facility. General Aldabergenov explained its importance: "It is a reflection of the commitment of our two nations to develop and enhance our mutual cooperation and understanding. The renovation of this facility enables KAZBRIG to improve English-language skills, operational readiness, and planning capabilities to conduct peacekeeping operations as part of United Nations-sanctioned multinational operations," he said, adding "Achieving these critically vital goals is important to local, regional, and global security and stability." ${ }^{64}$

NATO defines as a key area of its security cooperation with Kazakhstan the future development of the country's PSO capabilities: "Kazakhstan has allocated an airborne assault battalion as a peacekeeping battalion for potential deployment in NATOled peace support operations, under UN Security Council mandates. Elements of the peacekeeping battalion have joined NATO Allies in a number of live exercises. In the framework of PARP, one of the major projects is the expansion of this force into a brigade structure (KAZBRIG), giving Kazakhstan the capability to sustain a battalion sized contribution through rotation." ${ }^{65}$

To mitigate the potential problems that might arise in pursuing such cooperation, Astana correctly opted to limit the experiment with NATO interoperability to one air assault brigade drawn from the airmobile forces, as it would simply have proved to be impossible to involve all their air assault brigades in the experiment. At any time during this period, Kazakhstan's defense ministry planners understood that at least one air assault brigade had to be on standby for possible involvement in CSTO operations. The officer mentality, doctrine, manning, tactics, weapons, and equipment could not simultaneously straddle Western and Russian approaches to operations.

As Kazakhstan's relations with NATO, progress in developing KAZBRIG, and its interest in enhanced international commitments evolved, so too did its experience

63 Ben Fisher, "KAZBRIG Relocates English Language Training to the Tien Shan Mountains," Jly 2007; available at http://www.britishcouncil.org/pep27.pdf.

${ }^{64}$ Julie Shoemaker, "Peacekeeping Brigade Training Center Opens in Kazakhstan," 21 July 2010; available at http://www.tam.usace.army.mil/MED10-07-21-03.asp.

65 "NATO's Relations With Kazakhstan," available at http://www.nato.int/cps/ru/SID4B525DED-EE8E41DE/natolive/topics_49598.htm? selectedLocale=en. 
of the CSTO. In the aftermath of the Russia-Georgia war, Moscow pressed very hard to strengthen the military capabilities of the CSTO, and garnered support within the organization to form new Collective Rapid Reaction Forces (Kollektivnye Sil Operativnogo Reagirovaniya, or KSOR). Other CSTO members, such as Belarus and Uzbekistan, were less enthusiastic, basing their objections on principle, domestic political interests and limits, as well as raising issues concerning the overall future direction of the organization. However, from its informal inception in February 2009, Kazakhstan has assigned an air assault brigade to the KSOR, the $37^{\text {th }}$ Air Assault Brigade based in Taldykorgan, which further limits the future scope to expand PSO cooperation with NATO, as there seems to be no organic link between this structure and KAZBRIG. Were KAZBRIG to deploy, it could currently also draw on personnel from the $35^{\text {th }}$ Air Assault Brigade in Kapchagai. In a hypothetical crisis requiring the deployment of the entire brigade assigned to the KSOR, the country must also have sufficient brigade-level backup in order to replenish or rotate these deployed forces.

Raising the level of interoperability between NATO forces and KAZBRIG has not been without its challenges and setbacks. The highest level of interoperability is in $1^{\text {st }}$ Battalion, with limited progress in $2^{\text {nd }}$ Battalion and delays in forming $3^{\text {rd }}$ Battalion. There is also a critically important personnel issue, since in modern operations such as PSOs the standard of training and sophistication is such that the presence of conscripts severely inhibits operational capability. Kazakhstan's constitution prohibits the deployment of conscripts abroad. A political decision to fully professionalize the structure is being considered, which if implemented would give the country a PSO capability unique both among Kazakhstan's Central Asian neighbors, as well as Russia. In terms of its $37^{\text {th }}$ Air Assault Brigade, in the event of a CSTO operation, conscripts would be left behind. Nonetheless, NATO military planners are frustrated by the presence of high numbers of conscripts within the battalions in KAZBRIG, which reduces deployment options. Progress had been made by Kazakhstan in raising the standards of contract non-commissioned officers (NCOs) within KAZBRIG, though this is offset by retaining disproportionate numbers of conscript personnel.

In this context, the ceiling is fixed on a maximum of one brigade (KAZBRIG), from which only certain elements may be sent into future international PSOs: that means a maximum of one deployed battalion. However, as part of KAZBRIG progressed towards achieving a level of NATO interoperability, pressure mounted from London and Washington for the deployment of a company on a rotational basis in an international PSO. Since KAZBAT ended its deployment in Iraq in 2008, it has been abundantly clear that the nature of such requests at the NATO level could mean only one operation: joining ISAF in Afghanistan. 


\section{KAZBRIG: To Deploy or Not Deploy in Afghanistan?}

Paradoxically, although the designation of at least partial NATO interoperability in elements of KAZBRIG met with high political esteem in Kazakhstan, not least since this achievement is unique in the Alliance's cooperation with militaries in Central Asia, it also inevitably raised the stakes in terms of pressure to use these forces in operations abroad. The engineering element drawn from KAZBAT/ KAZBRIG, not exceeding more than twenty-seven personnel at any one time, who served in demining operations in Iraq from August 2003 to October 2008 also fed hopes in Western capitals that Astana might be open to sending its NATOtrained personnel to Afghanistan. London, Washington, and Brussels undoubtedly intensified their diplomatic efforts to convince the government of Kazakhstan of the merits of committing to such a controversial deployment. Part of the complex nature of the problems involved in this process related to the perception in Astana that Western governments were either attempting to "compel" a decision, which aroused puzzlement in the absence of sufficient political leverage, and the concern that perhaps underlying Western defense cooperation was an intention to simply use the country to suit Western interests.

Following the successful annual "Steppe Eagle" military exercise in Kazakhs$\tan$ in September 2008, involving KAZBRIG and forces from the U.S. and U.K., discussions were held on inviting Astana to join ISAF. On 20 November 2008, Kanat Saudabayev, then Kazakhstan's State Secretary, told a plenary session of the NATO parliamentary assembly in Valencia that Astana was considering joining ISAF and sending officers to work in military hospitals in Afghanistan. ${ }^{66}$ There were additional indications that Astana's potential contribution to ISAF was under discussion at the highest levels. On 14 January 2009, the Commander of United States Central Command (CENTCOM), General David Petraeus, visited Kazakhstan. Petraeus met senior defense officials, including Lieutenant-General Bolat Sembinov, the deputy defense minister responsible for cooperation with the West. Discussion centered on the five-year bilateral military cooperation plan. In his public diplomacy, Petraeus praised Kazakhstan's "military achievements," as well as its support for the NDN, and stressed that the country was his first stop on his tour of the region. "This is recognition of the fact that Kazakhstan plays a very important role, not only at the regional level but also internationally. It is a great honor for me to be a partner of the Kazakh military," he said. In the context of the surge strategy for the military campaign in Afghanistan, Petraeus and Sembinov visited KAZBRIG in Kapchagai, awarding medals to personnel for their service

66 See: Roger N. McDermott, "Azerbaijan and Kazakhstan Withdraw from Iraq: Shifts in Eurasian Peacekeeping Politics," Central Asia-Caucasus Analyst (26 November 2008). 
in Iraq. It appeared that the visit was more than simply a public relations event, and almost certainly included discussion on what more Kazakhstan may do to assist ISAF. ${ }^{67}$

In May 2009, Viktor Litovkin, the editor of the Moscow-based publication Nezavisimoye Voyennoye Obozreniye (Independent Military Review) assessed the possibility of Kazakhstan sending military personnel to Afghanistan. Litovkin reported on the visit to Kazakhstan earlier in the same month by Robert Simmons, Special Representative for the South Caucasus and Central Asia to the NATO Secretary-General. Simmons had officially invited Kazakhstan to participate in peace support operations in Afghanistan, and confirmed that all the necessary documents had been conveyed to Astana. The NATO official praised Kazakhstan's military, and referred to the level of "tactical interoperability" achieved with NATO forces, and consequently its potential to make a valuable contribution to ISAF. "The decision to send peacekeepers to Afghanistan or not will be made by Kazakhstan itself," Simmons said. Litovkin noted that Astana was "pondering" the request. ${ }^{68}$

While this "pondering" continued, senior Kazakhstani officials made no secret that deliberation on the sensitive issue was ongoing. Talgat Kaliyev, a foreign ministry official, addressed a conference on Kazakhstan's upcoming chairmanship of the Organization for Security and Cooperation in Europe (OSCE) held at the Center for Security and International Studies (CSIS) in Washington on 11 June 2009. Kaliyev's speech covered a broad range of issues, including the economic development of the country, its relations with the U.S., the "Path to Europe" initiative as a reciprocal response to the EU's Strategy for Central Asia 20072013, as well as Kazakhstan's regional and international partnerships. Stressing that one of the priorities in Kazakhstan's partnership with NATO is Afghanistan, Kaliyev stated: "Important steps in this direction may become the conclusion of an agreement on railway transit through Kazakhstan's territory to assist the work of the ISAF and possible involvement of Kazakhstan in the NATO operation, to be carried out in Afghanistan by sending two military officers of the Republic of Kazakhstan to serve in the ISAF headquarters and a medical detachment to ISAF military hospitals." ${ }^{69}$ In August 2009, NATO officials avoided public comment on

${ }_{67}$ Roger N. McDermott, "Kazakhstan's Peacekeepers Penciled in for Afghanistan?" Eurasia Daily Monitor 6:15 (23 January 2009).

68 Victor Litovkin, "NATO Officially Invited Kazakhstan to Send its Peacekeepers to Afghanistan," Nezavisimaya Gazeta (14 May 2009).

69 Remarks by Talgat Kaliyev, Ministry of Foreign Affairs of Kazakhstan, at the INDCSIS conference “Kazakhstan's OSCE Chairmanship Agenda," Washington, D.C., 11 June 2009; available at http://ind-dc.org/20090611000009.pdf. 
the issue, but privately confirmed to researchers that Astana was seriously considering its request to participate in ISAF. ${ }^{70}$ It appears that in preparation for the country chairing the OSCE, the NATO request was being more actively discussed at the highest levels of Kazakhstan's government.

In this context, and given the high priority assigned to Afghanistan during Kazakhstan's chairmanship of the OSCE in 2010, signs of movement towards a favorable response to the NATO request were apparent in Astana's diplomatic activity. While the decision-making process occurred largely in the background, away from press attention, in May 2010 speculation emerged in the Kazakhstani media that Astana was inching towards sending military personnel to Afghanistan. On 22 May 2010, the privately-owned Almaty-based socio-political weekly, Novoye Pokoleniye, highlighted a recent trip to Kabul by the thenForeign Minister Kanat Saudabayev. The official purpose of his talks with Afghanistan's President Hamid Karzai was to explore the nature of Astana's largely humanitarian initiatives as part of its OSCE agenda. Saudabayev confirmed that Kazakhstan would step up its humanitarian assistance to Afghanistan, commencing in 2010 with the allocation of USD 50 million over five years to train Afghan specialists in secondary-vocational and higher education establishments in Kazakhstan. Starting in 2010, Kazakhstan would enroll 200 Afghan students annually to train them in various professions, including medics, teachers, law enforcement and border security specialists, and journalists. Astana also aimed to strengthen regional border security, increase trans-border cooperation, and enhance law-enforcement activities. However, the article used an argument based on silence: that is, while much emphasis in Kazakhstan's OSCE agenda was devoted to raising the profile for potential PSOs in hotspots including Karabakh and Transnistria, it preferred to stress the humanitarian approach to the situation in Afghanistan. ${ }^{71}$

Indeed, the article not only speculated that Saudabayev had sounded out Karzai on the prospect of Kazakhstan joining ISAF, it linked the issue to the Obama Administration's surge policy in support of OEF and to Astana, possibly seeking a tradeoff between agreeing to deploy forces and securing Washington's diplomatic support to hold an OSCE summit in Kazakhstan. ${ }^{72}$ Despite such speculation on the nature of Kazakhstan's diplomacy on the issue of contributing to ISAF, a lengthy gestation period precipitated the public announcement on joining ISAF. On 19 February 2010, Kazakhstan's Senate Speaker Kasym-Zhomart Tokayev told the OSCE Parliamentary Assembly in Vienna,

70 Rebecca Moore confirmed that NATO officials had discussed this during August 2009 in the course of her research. See Rebecca Moore, "NATO's Partners in Afghanistan: Impact and Purpose," UNISCI Discussion Papers, No. 22 (January 2010); available at http://www.ucm.es/info/unisci/revistas/UNISCI\%20DP\%2022\%20-\%20MOORE. pdf.

71 Farida Galiyeva, “All Roads Lead to Kabul,” Novoye Pokoleniye (22 May 2010).

72 Ibid. 
"We plan to send four officers to the headquarters of this international force in Kabul. They will be the first representatives of Central Asia to join such a mission." ${ }^{73}$ In November 2010, on the sidelines of the NATO Summit in Lisbon, President Nazarbayev reaffirmed the commitment: Astana had agreed to join ISAF, at least in some form. ${ }^{74}$

Despite the amount of time involved in reaching a decision, careful and meticulous planning on the timing of the announcement, and deliberation on the nature of an initial deployment, the path to ratification proved to be more problematic. On 18 May 2011, the Majlis voted in favor of the NATO-Kazakhstan agreement on Kazakhstan's involvement in $\mathrm{ISAF}^{75}$ The historic vote by the lower house of parliament in favor of sending military forces to Afghanistan to serve as part of the ISAF HQ in Kabul echoed remarks made by earlier President Nursultan Nazarbayev in his address to the North Atlantic Council on Afghanistan during the NATO Summit in Lisbon in November 2010. Nazarbayev emphasized that Kazakhstan would become the first Central Asian country to join ISAF. Nonetheless, Astana was in no doubt that the issue would remain politically sensitive, conscious of the fierce opposition to such a move within various strata of society. Members of the Majlis were aware that the constitution required approval by both houses of parliament before the agreement could be signed by President Nazarbayev authorizing the deployment of members of the Kazakhstani armed forces abroad. Following the vote in the lower house of parliament, Sat Tokpakbayev, Majlis deputy and former Defense Minister, stressed that it was not a question of "bringing the Armed Forces of the Republic of Kazakhstan to the territory of Afghanistan," but that the decision only involved sending four officers to the ISAF HQ in Kabul. Tokpakbayev explained that one of these four officers would be a medic, and that ultimately the defense ministry would decide on the precise composition of the small contingent. ${ }^{76}$

Tokpakbayev also responded to reported threats made by the Taliban to target Kazakhstan in the event that the deployment occurred; understandably, he downplayed the threat. Moreover, Tokpakbayev reiterated the government's position on its efforts to assist in stabilizing Afghanistan, with its priority placed firmly on hu-

73 "Kazakhstan Will Send Servicemen to Afghanistan - Senate Speaker," Interfax (19 February 2010).

74 "President Nazarbayev told the NATO Summit in Lisbon that the country had joined ISAF," 22 November 2010; available at http://portal.mfa.kz/portal/page/portal/mfa/ resources/Pictures/Astana\%20Calling\%202010\%20\%28PDF\%29/Astana\%20Calling\%20112310.pdf.

75 Detailed information on the 18 May 2011 vote is available on the official Majlis website, at http://www.parlam.kz/ru/mazhilis/news-details/id5943/1/1.

76 "Kazakhstan to Send Four Servicemen to Afghanistan - Parliamentarian," Interfax (23 May 2011); “Kazakhstan May Supply Resources to ISAF - Nazarbayev," Interfax (22 November 2010). 
manitarian aid. ${ }^{77}$ Indeed, in Lisbon in November 2010, Nazarbayev had offered his backing for the planned withdrawal of NATO forces from Afghanistan, stressing that alongside this policy additional support would be required for the socio-economic reconstruction of Afghanistan. In Nazarbayev's view this process might allow Kazakhstan to become a "convenient supplier of resources to the ISAF," providing food, construction materials, and personnel training. Explaining why the country had prioritized the stabilization of Afghanistan during its chairmanship of the OSCE in 2010, Nazarbayev stated, "That was only natural, because Kazakhstan had been helping the international coalition for years and had become the first Central Asian state to join the ISAF." ${ }^{78}$

Experts in Kazakhstan were divided on the Taliban threat to the country and its implications were the deployment to Afghanistan to proceed. ${ }^{79}$ Dosym Satpayev, an Almaty-based political expert, suggested the deployment might lead to "an outbreak of extremism" within Kazakhstan. "The problem is that extremist and terrorist organizations operating in Central Asia may use the Taliban appeal as a pretext for perpetrating a terrorist act on the territory of Kazakhstan," Satpayev said, adding that groups such as Uzbekistan's Union of Islamic Jihad might use the Taliban's threat to instigate terrorism in Kazakhstan. Satpayev also based this statement upon the suicide bomb attack on 24 May 2010 in Aktobe, the administrative center of Aktyubinsk region, which was the country's first experience of a suicide bombing. ${ }^{80}$

Others were less concerned by the Taliban threat. Maksim Kaznacheyev, a political scientist in the Institute of Political Solutions, considered that the Taliban's threat to the country in response to the decision to send military personnel to Afghanistan was simply exaggerated. ${ }^{81}$ Kaznacheyev noted the predictability of the reported Ta-

77 Ibid.

78 Ibid.

79 In terms of the Taliban statement itself, which referred to "hundreds" of Kazakhstani troops being sent to Afghanistan, it may be that some believed Astana had planned to send or participate in a Provincial Reconstruction Team (PRT), rather than sending a small number of officers to ISAF HQ.

80 There appeared to be no evidence of any link between the Taliban and the bombing in Aktobe or the car bombing in Astana on 24 May 2011. Russian experts also question the possibility of such a link. See "Explosions in Astana and Aktobe May Be Linked to Extremists in North Caucasus-Expert," Interfax-Kazakhstan (8 June 2011); "Sending Kazakh Servicemen to Afghanistan May Trigger Outbreak of ExtremismExpert," Interfax-AVN (23 May 2011).

81 The U.S. Charge d'Affaires, John Ordway, downplayed the Taliban threat to Kazakhstan over the Majlis vote in favor of joining ISAF. The announcement, as such, in his view did not actually raise the threat level to Kazakhstan. "Press Opportunity with Charge d'Affaires John Ordway at University of Law and Humanities, Astana, Kazakhstan," U.S. Embassy in Astana, 23 May 2011; available at http://kazakhstan. usembassy.gov/tr-05-23-11.html. 
liban response, and stressed that Astana's decision to send officers to ISAF would create favorable circumstances to facilitate the country's closer cooperation with its Western partners, including the U.S. Murat Laumulin, senior research analyst in the Strategic Research Institute under the President of Kazakhstan (KISI), told InterfaxKazakhstan that the Taliban is not capable of organizing terrorist attacks in Kazakhstan, although Laumulin did admit that the Taliban may "theoretically" strike against Kazakhstan's embassies in Kabul or Islamabad. ${ }^{82}$

In the hiatus between the lower and upper houses sitting to consider the issue of approving the deployment of Kazakhstani military personnel to Afghanistan, the Republic's Society of Afghan War Disabled made a particularly emotional appeal against the initiative. The group's chairman, Sergei Mahashev, told a press conference in Almaty on 1 June 2011 that the veterans' organizations planned a campaign to collect signatures against the Majlis-adopted bill. Mahashev characterized the campaign as "No to a New War," betraying the misperception among veterans concerning the substance of the planned deployment, arguing that the country might be drawn into the war. "The Americans have failed to reach their goals in Afghanistan and now are planning to withdraw. In order to shake off [the] Taliban, they want to set [the] Taliban against us," Mahashev said. ${ }^{83}$

As the controversy over the proposed involvement in ISAF became public, with misinterpretation and inflammatory statements permeating the comments made by its critics, the defense ministry issued a statement on 25 May 2011 in an effort to address concerns about the plans, which stated: "An agreement between Kazakhstan and NATO does not mean that Kazakh servicemen will be involved in military operations in Afghanistan." On the contrary, the agreement simply provided the legal basis for servicemen from Kazakhstan to participate in the work of ISAF headquarters in Kabul. This would entail sending only four officers to ISAF HQ, and these were described in the statement as coordination officers, an information analyst, and a medical officer. "So, the sending of the Kazakh servicemen to the headquarters of the ISAF will help provide assistance to Afghan authorities in settling the situation their country," the statement concluded. ${ }^{84}$

Foreign ministry officials were equally keen to stress the limited nature of the deployment and the subtle distinction between sending officers to work in the ISAF HQ in Kabul as opposed to becoming directly involved in combat operations. On 23

82 "Pundits Downplay Terror Threats Over Kazakh Plans To Help ISAF In Afghanistan," Interfax-Kazakhstan (23 May 2011).

83 "Kazakhstan's Afghan Veterans Decry Plans to Assign Kazakh Military Servicemen to Afghanistan," Interfax-Kazakhstan (June 2011).

84 "Kazakh Officers Will Not Take Part in Combat Operation in Afghanistan-Ministry," Interfax-Kazakhstan (25 May 2011). 
May 2011, the spokesman for the foreign ministry, Askar Abdrakhmanov, briefly outlined the nature of the NATO-Kazakhstan agreement, which "stipulates sending four (Kazakh) officers to Kabul to work at the ISAF headquarters in Afghanistan," to be rotated every six months. Abdrakhmanov continued: "That is, what is at issue is not sending a contingent of Kazakhstan's armed forces, but participating in international assistance, recognized by the UN, to the government and parliament of Afghanistan in ensuring security and restoring peaceful life in that country." ${ }^{85}$

By 27 May, in the aftermath of the bombing in western Kazakhstan, in which there was no evidence of any link to the Taliban, Foreign Minister Yerzhan Kazykhanov stressed that by sending military personnel to Kabul, the country was operating strictly within the mandate of UN Security Council. "I would like to stress that this means that four Kazakh servicemen will be sent to Kabul under the UN Security Council's resolution. Our officers' main task is to help the Afghan government and people in their transition to a peaceful life," Kazykhanov told members of the Majlis in Astana. In fact, the text of his speech, issued later by the foreign ministry, omitted any mention of NATO, and rooted the comments in terms of avoiding going beyond the scope of the UN. "The UN Security Council is the sole international body that bears responsibility for the maintenance of international peace and security. In other words, it will be simply incorrect to say that we are acting beyond the scope of the UN mandate. Kazakhstan, as a responsible member of the United Nations, supports all international efforts aimed at stabilizing the situation in this country. We also share the view that there is no military solution to the Afghan problem," Kazykhanov added. ${ }^{86}$

Kazakhstan's upper house of parliament, the Senate, convened on 9 June 2011 to debate and vote on the possible ratification of the NATO-Kazakhstan agreement before presenting the bill for presidential signature. The Senate's vote against the agreement resulted in speculation in Astana and internationally concerning the possible motives underlying the "failure." The Reuters news agency reported the rejection of the bill, and highlighted the rare instance of discord between the two chambers of parliament, while Russian news agencies stressed that the deal with NATO had been flatly rejected. ${ }^{87}$

\footnotetext{
85 "Kazakhstan Says Sending Only Four Officers to Work at ISAF in Afghanistan," Interfax-Kazakhstan (23 May 2011).

86 “Kazakhstan Sending Troops to Afghanistan Under UN Mandate-Minister," InterfaxKazakhstan (27 May 2011).

87 "Kazakhstan Senate Rejects Plan to Send Servicemen To Afghanistan," Reuters (9 June 2011); "Kazakh Upper House Rejects Bill to Send Troops to Afghanistan," RIA Novosti (9 June 2011); "Kazakhstan's Parliament Refuses to Send Troops to Afghanistan," Russia Today (9 June 2011).
} 
Some senators feared that approving the bill would jeopardize Kazakhstan's reputation as a peaceful country, though such sentiments were evidently rooted in the misapprehension that a combat role was envisaged for Kazakhstani troops. One senator, Svetlana Dzhalmagambetova, certainly based her comments to the media on an assumption that Kazakhstan risked being drawn into the war in Afghanistan. Explaining that the Senate's "rejection" was the correct decision to make in the circumstances, Dzhalmagambetova said the debate was "heated" and added, "The bill would send Kazakhstan slipping gradually into war in Afghanistan. We could not allow that to happen." The senator elaborated by saying that, since Washington was pursuing an exit strategy from its military commitment to Afghanistan, Astana should avoid a hasty last-minute involvement that could damage the country's reputation. Other senators, such as Tasbai Simambayev, defended the vote on the grounds that the Senate had "every reason" to reject the plan, "We should safeguard the peace and accord in our country. Our foreign policy should be to keep neutrality. Such a position would also be in line with public opinion," he said. ${ }^{88}$

Undoubtedly, there were senators hostile to backing any move to join ISAF, among whom some were opposed on principle to any military involvement in Afghanistan. Furthermore, the idea that the Senate had taken a principled approach gained ground in some reports supported by the opinions of experts. Aziz Arianfar, the Director of the Center for Afghanistan Studies and Research, linked the Senate's refusal to ratify the agreement to grounds of national security: "The government of Kazakhstan wishes the soonest settlement of the Afghan problem but there are fears that the Taliban and other extremists may use the goodwill move by Kazakhstan as a pretext for listing Kazakhstan as an aggressor." ${ }^{" 89}$

Despite outright opposition to the agreement among some senators, the actual modus operandi was technical. Mukhtar Altynbayev, a member of the Senate's International Affairs, Defense, and Security Committee, and a former defense minister, exhorted senators to follow his lead and vote against the bill. Altynbayev in fact tabled a procedural issue, highlighting Point 5, Article 53 of the constitution, which stipulates that such decisions require a joint session of both chambers. The "rejection" when it came was neither final nor outright. ${ }^{90}$

Altynbayev's intervention suggests that the timing of the vote proved to be premature. There is no doubt that the Senate considered the ratification of the NATO-

\footnotetext{
88 "Not Sending Troops to Afghanistan the Right Decision-Senators," Interfax-Kazakhstan (9 June 2011).

89 "Sending Kazakh Servicemen toAfghanistan Will Endanger National Security-Expert," Interfax-AVN (9 June 2011).

90 "Senate Refuses to Send Kazakh Servicemen to Afghanistan," Interfax-AVN (9 June 2011).
} 
Kazakhstan agreement on joining ISAF to be both controversial and potentially divisive. Equally, there were numerous instances of senators either misunderstanding or exaggerating the nature of the agreement and it implications. Based upon earlier statements by defense and foreign ministry officials, the four officers were to constitute two military intelligence officers, a logistics (some reports indicate "administrative") officer, and a medical officer (epidemiologist) drawn from KAZBRIG. Not only were these officers intended only to serve within ISAF HQ in Kabul, but also there was no evidence of any planned combat role. Indeed, they were in effect combat service support officers, rather than combat support, and as such there were no indications whatever that these Kazakhstani military personnel would become engaged in combat operations. ${ }^{91}$

\section{Assessing the Implications of Astana's Support for ISAF}

Assessed in the wider context of Kazakhstan's partnership with NATO, its commitment to developing its PSO capabilities, and the lengthy governmental discussions on joining ISAF, it is likely that a confluence of several factors resulted in senators drawing back from voting in favor of the measure. Since the announcement of the political decision to deepen the country's level of assistance to ISAF in this manner, not only had the issue become more acutely controversial domestically, but the wider context had also changed. Instances of Western or Kazakhstani expert opinion either underestimating the significance of the plan to send four officers to Kabul, or wrongly making comparisons with the level of smaller deployments by ISAF members, masked the real political motivations in Astana, and thus the deeper complexities in the ratification debate proved elusive. ${ }^{92}$

Although there was no evidence that the bombings in Kazakhstan in May 2011 were in any way linked to the Taliban threat in response to the vote by the Majlis, it aroused a level of uncertainty among some senators and prompted a desire to at least take more time to reexamine any security risks that might be incurred by pursuing the policy. This cautious approach fed into what was ultimately a delayed ratification. It was also becoming clearer that the commitment by the Obama Administration to fulfill its promise to begin a gradual withdrawal from Afghanistan and hand over responsibility for the security of the country to the Afghan government was inching towards implementation, despite the divisions exposed by this policy both among NATO member states and domestically in Alliance capitals.

91 "Kazakhstan to Send Four Servicemen"; "Kazakhstan Says Sending Only Four Officers."

92 Farkhad Sharip, "Astana Hosts Islamic Economic Conference Downplaying Political Dimensions,” Eurasia Daily Monitor 8:117 (17 June 2011). 
Kazakhstani military personnel may in this transition period find themselves working more closely with their Afghan counterparts rather than solely alongside ISAF personnel, depending on the length of their commitment. It is also worth remembering that while no other Central Asian country has shown genuine interest in either developing NATO interoperable PSO forces or in sending servicemen to Afghanistan, for Astana this step was remarkable: it demonstrates that the country is willing to confront past sensitivities and not allow itself to be held captive to these or to dissuade the political leadership from participating in international stabilization efforts.

Arriving at an understanding of Astana's level of interest in diversifying and deepening its assistance to OEF and ISAF in Afghanistan since 2008 depends upon a range of factors. These relate to the chronology of its partnership with NATO, its response to shifts in the international security environment after $9 / 11$, the level of its bilateral defense cooperation with the U.S. and other Alliance members and how Kazakhstan's governmental structures manage these processes within the limits noted earlier. Not only does its geographical location bordering both Russia and China influence Astana's political considerations relating to NATO cooperation, but its close alliance and defense ties with Russia serves to frame the political-military scope for such activities. In contrast with Moscow, however, Astana has incrementally built closer ties with NATO, despite these geopolitical limitations. ${ }^{93}$

At a doctrinal level this is reflected in the new military doctrine adopted in 2007, especially compared with the earlier version in 2000. During the 1990s, NATO cooperation in Central Asia followed Washington's lead and prioritized Uzbekistan, which shifted in the following decade to place greater emphasis on Kazakhstan, not least due to OEF and fluctuations in U.S. relations in the region. Although reference to the country's defense relationship with the U.S. and its partnership with NATO should be viewed in the wider context of its cooperation with other states or membership in multilateral organizations, Kazakhstan's most recent military doctrine highlights these links more frequently and transparently. Indeed, the doctrine contains no negative reference to the Alliance, and even mentions "NATO standards" in terms of upgrading or re-equipping elements of its armed forces. ${ }^{94}$

Astana, of course, calibrates its assistance to ISAF primarily on the basis of its own national security interests, in which Afghanistan plays a significant but by no means determining role. Kazakhstan has consistently eschewed attaching primary place in the stabilization efforts in Afghanistan to a purely military solution, and also seeks to contribute constructively to the wider reconstruction efforts through its own initiatives and in other multilateral forums, such as through the OSCE or the SCO

\footnotetext{
93 Shaymergenov, "NATO In The Contemporary World."

94 Kazakhstan's 2007 military doctrine can be found at http://www.mod.gov.kz/mod-ru/ index.php?option=com_content $\&$ view=article $\& i d=63 \&$ Itemid=151.
} 
Afghanistan Contact Group. Laumulin has summarized the country's main security interests in this context as follows:

Kazakhstan's main objective is to strengthen the collective security system in Central Eurasia; that is, settle the Afghan problem and eliminate the threat posed by radical Islamism in general, as well as increase cooperation among all the security institutions operating in Central Asia-NATO, the CSTO, OSCE, and SCO (possibly also CICMA) — as a way to achieve this objective. ${ }^{95}$

While achieving a level of synergy between these multilateral organizations remains a foreign policy aspiration for Astana, it is also seeking progress towards its strategic security goal to settle the Afghan problem by maximizing attention on this issue in each forum. In other words, Kazakhstan's national security interests compel levels of cooperation within each organization that might further the longer-term pacification of Afghanistan. Meanwhile, as part of that wider strategy, it has actively supported the construction of alternative supply lines for ISAF in Afghanistan, and in addition to participating in the NDN it has devoted high-level political consideration to direct participation in ISAF, even if the latter has prompted domestic opposition and requires a delicate foreign policy balancing act. ${ }^{96}$

Kazakhstan's role in the NDN has not always attracted the high-profile publicity or international recognition afforded to other states, but this in no way detracts from the reality of that achievement or its potential future growth. NDN as an initiative to mitigate pressures on vulnerable supply lines through Pakistan has served to lessen the risks to such supplies, and reduce casualties among ISAF personnel. Kazakhstan, like other states assisting in the NDN, has already made an invaluable contribution to this effort. Astana's move to place part of this cooperation on a legislative footing is an important step that may assist in the further acceleration of NDN activity. ${ }^{97}$

Such potential is equally evident in the prospect of Kazakhstan actively participating in ISAF by deploying officers to Kabul, drawing on its unique achievement in the region by possessing PSO capabilities that have achieved a level of NATO interoperability. Paradoxically, given the controversial nature of any Central Asian state sending military forces to Afghanistan, this may become more likely in Kazakhstan's case as it becomes clear that such a policy is geared towards playing a supporting role that might transcend ISAF's current focus. Should elements of KAZBRIG be sent to Afghanistan, their function may be to assist the Afghan National Army. This process may be aided by a political decision, if reached, to fully professionalize KAZBRIG, which in turn has implications for the country's future participation in UN/NATO-led

\footnotetext{
95 Murat Laumulin, "Some Problems of Kazakhstan's Current Foreign Policy," Central Asia and the Caucasus Journal of Social and Political Studies 12:1 (2011): 119.

96 "NATO Experts Visit Kazakhstan."

97 "Kazakhstan Ratifies Afghan Cargo Air Transit Agreement."
} 
PSOs. The latent potential in this area is attested to by continued efforts to strengthen its ELT infrastructure as well as ensuring that KAZBRIG personnel continue to be familiarized with NATO standard PSO techniques, and hold the annual "Steppe Eagle" exercise. $^{98}$

Astana policy of incrementally improving practical defense and security cooperation with the U.S. and NATO assumes many forms, though it can often proceed at a pace that frustrates Western policy makers due to their tendency to view the country through a Euro-Atlantic prism. Equally, sensitivity to Kazakhstan's close relations with Russia can be taken too far, resulting in views and policy approaches that simply fail to take account of the country's development as well as changes in global economic and political conditions. As Russian experts on Central Asia explained to the author, there are aspects of Kazakhstan's policy planning that remain inaccessible - even to Russians. Ultimately, the extent to which Kazakhstan assists ISAF, participates in initiatives aimed at facilitating the drawdown of forces and the longer-term pacification of Afghanistan, or assists in the task of facilitating wider economic integration will remain in Kazakhstani hands.

98 Partnership for Peace Information Management System, Steppe Eagle (16 August 2010); Shoemaker, "Peacekeeping Brigade Training Center"; Fisher, "KAZBRIG Relocates English Language Training." 


\section{Bibliography}

Abdrakhmanov, Askar, and Timur Shaymergenov. "NATO in the Contemporary World and its Relations with Kazakhstan (According to an Expert Opinion Poll)." Central Asia And The Caucasus Journal of Social and Political Studies 6, no. 54 (2008): 43-54.

Antipov, Anatoliy. "VPK Is Prescribed for the Defense Establishment." Krasnaya Zvezda (2006).

Belousov, Yuriy. "People Are the Important Thing in the Armed Forces." Krasnaya Zvezda (2008).

British Military Advisory and Training Team (Czech Republic)., 2010.

Daly, John C. K.. Are ISAF's Tenuous Supply Lines Sustainable?. ISN, 2011.

Daly, John C. K.. Rerouting Logistics In Afghanistan. ISN , 2010.

Evseev, V. V.. "Afganskaya Problema: Vzglyad iz Moskvy." Nezavisimoye Voyennoye Obozreniye (2010).

Explosions in Astana and Aktobe May Be Linked to Extremists in North Caucasus-Expert. Interfax-Kazakhstan (2011).

Ferrero, Kathleen. Tanker's First Flight Over Top of the World Marks New Era In Efficiency., 2011.

Fisher, Ben. KAZBRIG Relocates English Language Training to the Tien Shan Mountains., 2007.

Full Text of China-Kazakhstan Joint Statement on All-Round Strategic Partnership. Xinhua Domestic Service, 2011.

Galiyeva, Farida. "All Roads Lead to Kabul." Novoye Pokoleniye (2010).

Haggerty, Alan E.. S\& T and Maneuver Warfare: A Current Success and a Future Challenge., 2008.

Kaliyev, Talgat. Kazakhstan's OSCE Chairmanship Agenda In Remarks at the INDCSIS conference. Washington, D.C., 2009.

Kangas, Roger D.. "Battling Misperceptions: Challenges to U.S. Security Cooperation in Central Asia." Joint Forces Quarterly 50 (2008): 98-104.

Katzman, Kenneth. Afghanistan: Post-War Governance, Security, and U.S. Policy. Washington, D.C.: Congressional Research Service, 2007. 
Kazakh Officers Will Not Take Part in Combat Operation in AfghanistanMinistry. Interfax-Kazakhstan (2011).

Kazakh Parliament Ratifies Treaty On Transit Of U.S. Cargo To Afghanistan. Interfax-Kazakhstan (2011).

Kazakh Servicemen Attend Seminar on NATO Peacekeeping Operations. Interfax- Kazakhstan (2011).

Kazakh Speaker, EU Envoy Mull Boosting Ties. Interfax-Kazakhstan (2009).

Kazakh Upper House Rejects Bill to Send Troops to Afghanistan. RIA Novosti, 2011.

Kazakhstan Advocates Closer Ties With NATO. Interfax (2010).

Kazakhstan Approves Path To Europe Program. Interfax (2008).

Kazakhstan Boosting Partnership with NATO-Envoy. Interfax-Kazakhstan (2010).

Kazakhstan Faces Serious 'Extremist Threats'-Analyst. Interfax (2011).

Kazakhstan May Supply Resources to ISAF - Nazarbayev. Interfax (2010).

Kazakhstan Ratifies Afghan Cargo Air Transit Agreement With The U.S. Interfax- AVN (2011).

Kazakhstan Says Sending Only Four Officers to Work at ISAF in Afghanistan. Interfax-Kazakhstan (2011).

Kazakhstan Senate Rejects Plan to Send Servicemen To Afghanistan. Reuters, 2011.

Kazakhstan Sending Troops to Afghanistan Under UN Mandate-Minister. Interfax-Kazakhstan (2011).

Kazakhstan to Send Four Servicemen to Afghanistan - Parliamentarian. Interfax (2011).

Kazakhstan Will Send Servicemen to Afghanistan - Senate Speaker. Interfax (2010).

Kazakhstan's Afghan Veterans Decry Plans to Assign Kazakh Military Servicemen to Afghanistan. Interfax-Kazakhstan (2011).

Kazakhstan's Parliament Refuses to Send Troops to Afghanistan. Russia Today, 2011. 
Khripunov, Igor. The Politics and Economics of Russia's Conventional Arms Transfers In Dangerous Weapons, Desperate States. New York: Routledge, 1999.

Kuchins, Andrew C., and Thomas M. Sanderson. The Northern Distribution Network and the Modern Silk Road: Planning for Afghanistan's Future. Washington, D.C.: Center for Strategic and International Studies, 2009.

Kuchins, Andrew C., and Thomas M. Sanderson. The Northern Distribution Network and Afghanistan. Washington, D.C.: Center for Strategic and International Studies, 2010.

Laumulin, M.. "Strategicheskie Aspekty Otnosheniy Kazakhstana s Zapadom: SSha, NATO." In Kazakhsta v Sovremennom Mire: Realii I Perspektivy. Almaty: KISI, 2008.

Laumulin, Murat T.. The Geopolitics of the 21st Century In Central Asia. Almaty: KISI, 2007.

Laumulin, Murat. "Some Problems of Kazakhstan's Current Foreign Policy." Central Asia and the Caucasus Journal of Social and Political Studies 12, no. 1 (2011): 119.

Litovkin, Victor. "NATO Officially Invited Kazakhstan to Send its Peacekeepers to Afghanistan." Nezavisimaya Gazeta (2009).

McCarthy, Michael J.. The Limits of Friendship: U.S. Security Cooperation In Central Asia. Maxwell Air Force Base, AL: Air University Press, 2007.

McDermott, Roger N., and Igor Mukhamedov. Kazakhstan's Peacekeeping Activities In Iraq. Almaty: Bagdar, 2004.

McDermott, Roger N.. "Enhancing Kazakhstan's Peacekeeping Capabilities: Interoperability and Regional Cooperation." Central Asia And The Caucasus, Journal of Social and Political Studies 2, no. 26 (2004): 70-82.

McDermott, Roger N.. "Kazakhstan's Peacekeepers Penciled in for Afghanistan?" Eurasia Daily Monitor 6, no. 15 (2009).

McDermott, Roger N.. Azerbaijan and Kazakhstan Withdraw from Iraq: Shifts in Eurasian Peacekeeping Politics. Central Asia-Caucasus Analyst, 2008.

Military Surface Deployment and Distribution Command Customer Advisory., 2010.

NATO Can Help Kazakhstan Conduct Army Reform-Official. Interfax (2011). 
NATO Experts Visit Kazakhstan To Boost Cooperation. Interfax-Kazakhstan (2010).

NATO Increases Afghan Cargo Transfers Through Central Asia. centralasiannewswire.com, 2011.

Nichol, Jim. Central Asia's Security: Issues and Implications for US Interests In Congressional Research Service Report. Washington, D.C., 2010.

Not Sending Troops to Afghanistan the Right Decision-Senators. InterfaxKazakhstan (2011).

Nurgaliev, M.. "Kazakh-US Military-Political Cooperation in the Context of US Geopolitical Interests in Central Asia." Central Asia And The Caucasus Journal of Social and Political Studies 2, no. 44 (2007).

Olcott, Martha. "NATO and Security in Central Asia." In Security Sector Reform in Central Asia: Exploring Needs and Possibilities, 63-72. Groningen: The Centre of European Security Studies (CESS), 2010.

Pundits Downplay Terror Threats Over Kazakh Plans To Help ISAF In Afghanistan. Interfax-Kazakhstan (2011).

Rumer, E.. "The U.S. Interests and Role in Central Asia After K2." Washington Quarterly (2006): 141-54.

Ryan, Kurt J.. Exploring Alternative Strategic Access To Afghanistan. U.S. Army War College, 2009.

Second Stage of Kazakh- NATO Partnership Plan Adopted. InterfaxKazakhstan (2010).

Senate Refuses to Send Kazakh Servicemen to Afghanistan. Interfax-AVN (2011).

Sending Kazakh Servicemen to Afghanistan May Trigger Outbreak of Extremism- Expert. Interfax-AVN (2011).

Sending Kazakh Servicemen toAfghanistan Will Endanger National SecurityExpert. Interfax-AVN (2011).

Sharip, Farkhad. "Astana Hosts Islamic Economic Conference Downplaying Political Dimensions." Eurasia Daily Monitor 8, no. 117 (2011).

Shaymergenov, Timur, and Marat Biekenov. "Kazakhstan and NATO: Evaluation of Cooperation Prospects." Central Asia And The Caucasus Journal of Social and Political Studies 11, no. 1 (2010): 46. 
Shlykov, Vitaly. "Spineless Army." Voyenno Promyshlennyy Kuryer (2011).

Shoemaker, Julie. Peacekeeping Brigade Training Center Opens in Kazakhstan., 2010.

Starr, S. F.. "A Partnership For Central Asia." Foreign Affairs 84, no. 4 (2005): 169.

Tazhin, M. M.. "Natsionalnaya Bezopasnost eto Bezopasnost Cheloveka." Tsentranaya Azia (2007): 6-10.

The Opening Up of the Alliance: Partnership for Peace: The Partnership for Peace Planning and Review Process (PARP) In NATO Handbook. Brussels: NATO, 2002.

The UK's Foreign Policy Approach to Afghanistan and Pakistan In Foreign Affairs Select Committee Report. London: House of Commons, 2011.

U.S. Shifts Supply Routes To Central Asia. Radio Free Europe/Radio Liberty, 2011.

U.S.-Kazakhstan Sign Five Year Defense Cooperation Plan. InterfaxKazakhstan (2008).

Voennaya Doktrina. Kazakhstanskaya Pravda (2007).

Zabortsevas, Yelena Nikolayevn. "Kazakhstan's Bilateral Economic Relations with Russia: a Robust Partnership?". BASEES 2010 Annual Conference, 2010. 